\title{
O RAZLIKAMA IZMEĐU TIPOVA FONETSKIH REALIZACIJA DUGOUZLAZNOG AKCENTA ${ }^{* *}$
}

U radu su opisane realizacije dugouzlaznog akcenta tipične za 12 govornica poreklom iz Beograda, Novog Sada i različitih delova istočnohercegovačkog dijalekta (BG, NS i IH grupa). Glavni zadatak istraživanja bio je da utvrdimo da li između realizacija akcenta u ovim grupama postoje razlike, odnosno, da li se odabrani akustički parametri u primerima iz ovih triju grupa statistički značajno razlikuju. Analizirano je 235 primera 14 dvosložnih i 7 trosložnih reči s dugouzlaznim akcentom. Podaci su poređeni s onima dobijenim prilikom ranijih ispitivanja ovih govora. Istraživanje je pokazalo da se kod govornica čiji smo govor ispitivali javljaju dva tipa fonetskih realizacija dugouzlaznog akcenta. Kada su u pitanju posmatrani parametri tona i intenziteta, između BG i IH grupe nema statistički značajnih razlika, dok takve razlike postoje između NS i BG, kao i između NS i IH grupe.

Ključne reči: dugouzlazni akcenat, frekvencija osnovnog tona, intenzitet, trajanje, govor Beograda, govor Novog Sada, istočnohercegovački dijalekat.

\section{UVOD}

Ispitivanja akustičkih karakteristika akcenata u standardnom srpskom jeziku koja sprovode istraživači kojima je srpski maternji jezik ${ }^{1}$, započeta šezdesetih godina XX veka čuvenim i značajnim studijama Pavla Ivića i Ilse Lehiste (Ivić-Lehiste, 2002), nastavljena radom Jelice Jokanović-Mihajlov (Jokanović-Mihajlov, 1983; 2007), u

\footnotetext{
*dsredojevic@ ff.uns.ac.rs

** Rad je urađen u okviru projekta Digitalne medijske tehnologije i društveno-obrazovne promene (III 47040), koji finansira Ministarstvo prosvete, nauke i tehnološkog razvoja Republike Srbije.

${ }^{1}$ Ovaj činilac ističemo kao naročito bitan, s obzirom na to da su se u radovima pojedinih proučavalaca ove oblasti javljali izvesni propusti u koncipiranju korpusâ i tumačenju podataka uzrokovani upravo činjenicom da oni nisu bili izvorni govornici srpskog jezika (Ivić-Lehiste, 1996: 165-169; Sredojević, 2017c: 202-204).
} 
poslednjih deset godina obogaćena su nekolikim doktorskim radovima vršenim s istim ciljem (Sredojević, 2011; Batas, 2016, Lončar Raičević, 2016a), kao i drugim radovima u kojima su ispitivane karakteristike akcenata u različitim štokavskim govorima - i novim i onim nečetvoroakcenatskim (Sredojević-Subotić, 2011a; 2011b; Sredojević, 2015; 2106a; 2016b; 2017a; 2017b; Lončar Raičević, 2016b; Lončar RaičevićSudimac, 2017; 2018). Preduzeta istraživanja u ovom sada već nemalom korpusu razlikuju se po mnogim kriterijumima: dijalekatskom poreklu govornika, sastavu i obimu analiziranog materijala, ali i po načinu obrade podataka i prezentovanju rezultata. Iako ova metodološka raznovrsnost, van svake sumnje, doprinosi boljem i detaljnijem sagledavanju prirode jedinica akcenatskog sistema srpskog jezika, ona, ujedno, otežava međusobna poređenja rezultata dobijenih u različitim istraživanjima. Drugim rečima, iako postoje opisi fonetskih realizacija akcenata govornika iz različitih krajeva, često se ne može reći da li se analizirani akustički parametri međusobno (statistički značajno) razlikuju, kao ni to da li eventualne razlike u realizaciji akcenata govornici mogu da opaze u komunikaciji. Ovaj je rad upravo pisan s ciljem da se utvrdi da li među fonetskim realizacijama istog akcenta - koje su tipične za različite govore na novoštokavskoj teritoriji - postoje razlike u pogledu parametara tona, intenziteta i trajanja. Kako nam obim rada ne dozvoljava da se bavimo svim akcentima, pažnju smo usmerili na dugouzlazni akcenat. Jedan od razloga je taj što među istraživačima ne postoji saglasnost po pitanju tipične fizionomije ovog akcenta, što utiče i na različite fonološke interpretacije pojma akcenta u srpskom jeziku. Naime, s jedne strane stoje rezultati do kojih su došli Ivić i Lehiste, po kojima je dugouzlazni akcenat (kao i kratkouzlazni) dvosložan, što znači da je kod njega ,visok ton na dve uzastopne more razdvojene slogovnom granicom" (Ivić-Lehiste, 1996: 25, 198), ${ }^{2}$ a razlikovanje dugih akcenata omogućava i tonsko kretanje unutar samog akcentovanog vokala (IvićLehiste, 1996: 58; 2002: 155), ${ }^{3}$ dok s druge strane stoje opisi ovog akcenta u govoru Novog Sada, na koje se uopšte ne mogu primeniti Ivićevi i Lehistini nalazi, kako je i dokazano u dosad najobimnijem istraživanju akcenata u srpskom jeziku (Sredojević, 2017c: 193-198). Upravo zbog toga, prvi zadatak bio je da opišemo tipične realizacije ovog akcenta kod govornica poreklom s teritorije dvaju dijalekata koji su poslužili kao osnovica za formiranje standardnog jezika. U fokusu su nam bili veliki kulturni i ekonomski centri na teritoriji šumadijsko-vojvođanskog dijalekta (Beograd i Novi Sad) i nekoliko većih mesta $s$ teritorije istočnohercegovačkog dijalekta. Glavni zadatak

\footnotetext{
${ }^{2}$ Ovim su, zapravo, Ivić i Lehiste potvrdili stavove do kojih je došao još Leonard Mazing (Masing, 1876).

${ }^{3}$ Isti zaključak u svojoj studiji navode Petrović i Gudurić (Petrović-Gudurić, 2010: 118).
} 
istraživanja bio je da utvrdimo da li između realizacija dugouzlaznog akcenta u ovim grupama postoje razlike, odnosno, preciznije, da li se odabrani akustički parametri, koji se inače posmatraju pri opisu akcenata u srpskom jeziku, u primerima iz ovih triju grupa statistički značajno razlikuju.

Opisi akcenata u posmatranim govorima biće poređeni s rezultatima do kojih se došlo u prethodnim istraživanjima akcenata u srpskom jeziku. Rezultate istraživanja Pavla Ivića i Ilse Lehiste (Ivić-Lehiste, 2002), zasnovane većinom na izgovoru samog Ivića, a jednim delom i na izgovoru dvanestoro dodatnih govornika (mahom vojvođanskog porekla) (Ivić-Lehiste, 2002: 11, 83-88), poredićemo s rezultatima izgovora naših govornica poreklom iz Novog Sada. Budući da je Jelica JokanovićMihajlov opisivala prirodu uzlaznih akcenata u progresivnijim štokavskim govorima i akcente i intonaciju govora na radiju i televiziji s beogradskog područja - njene ćemo rezultate porediti s rezultatima naših govornica iz svih triju grupa (Jokanović-Mihajlov, 1983; 2007). Opise akcenata do kojih je došao Dejan Sredojević, sam ili u koautorstvu s Ljiljanom Subotić, poredićemo s opisima akcenata naših govornica novosadskog porekla (Sredojević-Subotić, 2011a; Sredojević, 2015; 2017c), odnosno, s opisima akcenata govornica iz svih triju grupa (Sredojević-Subotić, 2011b), a tako ćemo porediti i rezultate do kojih je došla Ana Batas prilikom ispitivanja fonetske i akcenatske promenljivosti reči u kontinualnom govoru (Batas, 2014). Opise dugouzlaznog akcenta kod govornica poreklom iz istočnohercegovačkog dijalekta poredićemo i s opisima ovog akcenta do kojih je došla Aleksandra Lončar Raičević prilikom proučavanja prozodije reči u užičkom kraju (Lončar Raičević, 2016a).

\section{METODE I TEHNIKE ISTRAŽIVANJA}

\subsection{Govornice}

U radu su predstavljeni rezultati analize snimaka dvanaest govornica. Pet od njih rođeno je u Novom Sadu, koji im je sve vreme i prebivalište, studentkinje su Filozofskog fakulteta u Novom Sadu, na kojem je jedna već diplomirala. U nastavku rada to su govornice $N S$ grupe. Tri govornice rođene su u Beogradu, u kojem su živele do dolaska na studije na Akademiji umetnosti u Novom Sadu, a označene su kao govornice $B G$ grupe. Četiri govornice rođene su u različitim mestima na teritoriji istočnohercegovačkog dijalekta, u tim mestima su živele do dolaska na studije na Filozofskom fakultetu u Novom Sadu. Zbog istog dijalekatskog porekla i slične realizacije elemenata segmentnog i suprasegmentnog plana predstavljamo ih kao govornice $I H$ grupe (tabela 1 ). 
Tabela 1: Podaci o govornicama

\begin{tabular}{|c|c|c|c|c|}
\hline Inicijali & Oznaka & Mesto & Starost & Pol \\
\hline I. S. & G1 & Novi Sad & $22 \mathrm{~g}$. & $\overline{\mathrm{Z}}$ \\
\hline D. S. & $\mathrm{G} 2$ & Novi Sad & $20 \mathrm{~g}$. & Ž \\
\hline T. B. & G3 & Novi Sad & $19 \mathrm{~g}$. & $\check{z}$ \\
\hline M. C. & G4 & Novi Sad & $20 \mathrm{~g}$. & $\overline{\mathrm{Z}}$ \\
\hline G. K. & G5 & Novi Sad & $29 \mathrm{~g}$. & $\bar{z}$ \\
\hline A. V. & G6 & Beograd & $22 \mathrm{~g}$. & ž \\
\hline A. M. & G7 & Beograd & $20 \mathrm{~g}$. & $\overline{\mathrm{z}}$ \\
\hline J. Đ. & G8 & Beograd (Pančevo) & $22 \mathrm{~g}$. & $\bar{z}$ \\
\hline A. D. & G9 & Herceg Novi & $21 \mathrm{~g}$. & Ž \\
\hline B. B. & G10 & Nevesinje & $21 \mathrm{~g}$. & $\bar{z}$ \\
\hline S. R. & G11 & Milići & $21 \mathrm{~g}$. & $\overline{\mathrm{z}}$ \\
\hline R. B. & G12 & Gacko & $21 \mathrm{~g}$. & $\check{Z}$ \\
\hline
\end{tabular}

Snimanje je obavljeno u Fonetskom studiju Filozofskog fakulteta u Novom Sadu, uz stručnu pomoć profesionalnog snimatelja. Vreme reverberacije u studiju iznosi $0,3 \mathrm{~s}$, što omogućava vernost snimanog govora. Materijal je digitalno snimljen (frekvencija semplovanja: 44,1 kHz, rezolucija: 16 bita, softver: Sound Forge 8,0, mikrofon: Neumann U-67). Za audiograme korišćen je softver Audiopingvin, a analiza spektrograma izvršena je uz pomoć programa Praat verzija 4.6.06 (BoersmaWeenink, 2011).

Pri statističkoj obradi podataka korišćen je programski paket Statistical Package for Social Sciences - SPSS 21. Primenom Kolmogorov-Smirnov testa utvrđena je normalnost raspodele podataka. Za komparaciju vrednosti numeričkih obeležja između triju grupa primenjena je jednosmerna analiza varijanse (ANOVA). Kako bi se utvrdilo između kojih grupa postoji statistički značajna razlika korišćen je Bonferroni post hoc test. Statistički se značajnim smatraju vrednosti nivoa značajnosti $\mathrm{p}<0,05$.

\subsection{Korpus}

Reči odabrane za analizu nalazile su se u medijalnoj poziciji kraćih izjavnih rečenica koje nisu sadržale afektivnu leksiku, nisu bile realizovane kao fokus iskaza niti su se nalazile pored fokusa. Govornice su rečenice čitale sa ekrana računara koji je bio na optimalnoj udaljenosti ispred njih. Svaka rečenica bila je predstavljena na zasebnom slajdu prezentacije u programu PowerPoint, čime je izbegnuta uzlazna intonacija karakteristična za čitanje reči/rečenica sa spiska. Korpus je sadržao 14 dvosložnih i 7 trosložnih reči, a statističkoj je analizi podvrgnuto 235 primera rečî:

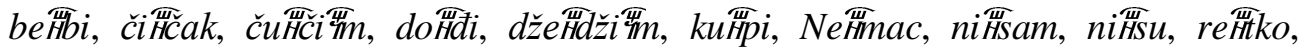




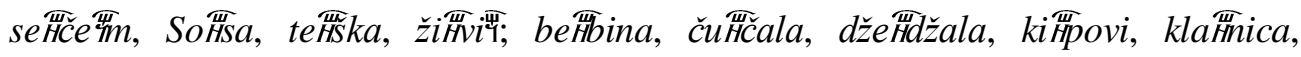

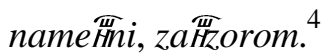

\subsection{Analizirani parametri}

Na osnovu analize spektrograma i oscilograma, u svakoj reči, izmerene su vrednosti frekvencije osnovnog tona (f0): na početku i kraju naglašenog vokala $\left(f O_{l p}\right.$, $\left.f O_{l k}\right)$ i na početku i na kraju vokala u narednom slogu $\left(f O_{2 p}, f O_{2 k}\right)$, kao i maksimalne vrednosti fO ovih dvaju vokala $\left(f O_{1 \max }, f O_{2 \max }\right)$. Ove su vrednosti izražene u hercima $[\mathrm{Hz}]$. Na osnovu tih podataka izračunat je raspon između početne i krajnje vrednosti f0 naglašenog vokala $-R\left(f O_{l p}-f O_{l k}\right)$, raspon između tonskih vrhunaca naglašenog i narednog vokala $-R\left(f O_{1 \max }-f O_{2 \max }\right)$, kao i raspon između kraja naglašenog i početka narednog vokala $-R\left(f O_{1 k}-f O_{2 p}\right)$. Vrednosti raspona izražene su u polustepenima $\mathrm{R}=$ $\left(12 \log _{10}(\mathrm{f} 2 / \mathrm{f} 1)\right) / \log _{10} 2$ (Baken-Orlikoff, 2000: 148)), što je omogućilo pouzdano poređenje rezultata dobijenih od različitih govornica ('t Hart-Collier, \& Cohen, 2006: 24).

Izmerene su vrednosti srednjeg intenziteta na naglašenom vokalu, kao i na vokalu koji dolazi posle njega $(I I, I 2)$, na osnovu čega je izračunata vrednost razlike intenziteta ovih dvaju vokala $(I 1-I 2)$. Sve vrednosti izražene su u decibelima $[\mathrm{dB}]$.

Analizom spektrograma utvrđeno je trajanje naglašenog i narednog vokala $(t 1, t 2)$, kao i trajanje od početka naglašenog vokala do tonskog vrhunca tog vokala $\left(t 1_{\text {max }}\right)$, a vrednosti su izražene u milisekundama [ms]. Kako bismo mogli međusobno porediti položaj tonskog vrhunca u različitim rečima, ovaj je podatak predstavljen preko ukupnog trajanja naglašenog vokala $\left(t 1_{\text {max } \%}\right)$ i izražen je u procentima. Isto tako, trajanje vokala koji sledi naglašeni vokal izraženo je preko ukupnog trajanja naglašenog vokala $(t 2(\% t 1))$ i izraženo je u procentima.

\section{REZULTATI I DISKUSIJA}

\subsection{BG grupa}

3.1.1. Kod $57 \%$ primera dvosložnih reči na naglašenom vokalu nalazi se ulazno tonsko kretanje (dosledno uzlazno kod 35\% primera), dok se u preostalim slučajevima sreće dosledno silazno tonsko kretanje. U grupi trosložnih reči na

$4 \mathrm{~S}$ obzirom na to da ni u jednoj od posmatranih grupa govornice nisu realizovale neakcentovanu dužinu, dvosložne, odnosno, trosložne reči ne razlikuju se po prozodijskom liku. 
naglašenom vokalu najčešće se javlja dosledno silazno tonsko kretanje. Ipak, s obzirom na to da su i kod dvosložnih i kod trosložnih reči između početka i kraja naglašenog vokala tonski intervali mali, najčešće manji od jednog polustepena možemo reći da je na ovom vokalu tonsko kretanje, zapravo, ravno. Kada je na naglašenom vokalu uzlazno-silazno tonsko kretanje, u grupi dvosložnih reči dominantniji je uzlazni deo, a vrhunac vokala nalazi se blizu samog kraja, dok je u grupi trosložnih reči dominantniji silazni deo, a vrhunac je bliže početku vokala. Između kraja naglašenog i početka narednog vokala postoji uzlazan tonski interval. Veoma retko, u primerima dvosložnih reči, između ovih dvaju vokala javlja se manji silazni tonski interval, ali je tada, najčešće, na naglašenom vokalu uzlazno tonsko kretanje. Tonskim odnosima između kraja naglašenog i početka narednog vokala odgovaraju odnosi maksimalnih tonskih visina ovih dvaju vokala. Na vokalu koji sledi naglašeni vokal tonsko je kretanje skoro uvek dosledno silazno kod dvosložnih reči, dok kod trosložnih ono može biti i uzlazno-silazno, s podjednakom zastupljenošću primera u kojima je veći uzlazni, odnosno, silazni deo. Finalni vokal u trosložnim rečima ima silazno tonsko kretanje. Tonski vrhunac reči nalazi se na naglašenom vokalu kod $60 \%$ primera dvosložnih reči, odnosno, na vokalu drugog sloga kod svih primera trosložnih reči. ${ }^{5}$

Naglašeni je vokal intenzitetski dominantniji i moguće ga je opaziti kao glasnijeg kod $60 \%$ primera dvosložnih i $38 \%$ primera trosložnih reči, dok se prvi nenaglašeni vokal opaža kao glasniji kod $12 \%$ dvosložnih, odnosno $30 \%$ primera trosložnih reči. U preostalim slučajevima, razlika intenziteta dvaju vokala manja je od $1 \mathrm{~dB}^{6}$, što znači da se oni opažaju kao vokali podjednake glasnosti.

3.1.2. Kada je tonsko kretanje u pitanju, rezultati našeg istraživanja saglasni su s rezultatima do kojih je došla Jelica Jokanović-Mihajlov opisujući govor studentkinje poreklom iz Beograda, kao i govor profesionalnih govornika na radiju i televiziji $\mathrm{s}$ beogradskog područja - u rečima s uzlaznim akcentima nema prave uzlaznosti, naglašeni vokal ima uravnjenu (ili čak silaznu) intonaciju, a između naglašenog i narednog vokala postoji karakterističan tonski skok (JokanovićMihajlov, 1983: 334; 2007: 70-91). Rezultati istraživanja kojeg ovde predstavljamo u skladu su s opisima dugouzlaznog akcenta kod govornikâ beogradskog porekla (Sredojević-Subotić, 2011b: 231-232). Ana Batas nalazi da kod govornikâ

\footnotetext{
${ }^{5} \mathrm{~V}$. primere na slikama 1 i 2.

${ }^{6}$ Vrednost od $1 \mathrm{~dB}$ jeste najmanja promena intenziteta koju možemo da opazimo kao promenu glasnosti (Everest, 2001: 70).
} 
poreklom iz Beograda (i Zemuna) ton može da raste do polovine drugog sloga, a zatim sledi manji pad (Batas, 2014: 283).

Kada je intenzitet u pitanju, Jokanović-Mihajlov nalazi da je u velikom broju primera intenzitet podjednako raspoređen između naglašenog i narednog vokala ili je pak veći na prvom nenaglašenom vokalu (Jokanović-Mihajlov, 1983: 330; 2007: 71-96).

\subsection{IH grupa}

3.2.1. Dosledno uzlazno tonsko kretanje na naglašenom vokalu nalazimo kod 38\% primera dvosložnih i 54\% primera trosložnih reči, dok se dosledno silazno tonsko kretanje sreće kod 31\% primera dvosložnih, odnosno, trosložnih reči. U preostalim slučajevima naglašeni vokal karakteriše uzlazno-silazno tonsko kretanje s dominantnijim ulaznim delom. U tim primerima, tonski vrhunac vokala nalazi se na samom njegovom kraju. Između kraja naglašenog i početka narednog vokala nalazi se uzlazni tonski interval. U malom broju primera dvosložnih reči između ovih dvaju vokala zabeležen je silazni interval manji od jednog poslustepena. Vokal u slogu koji prati naglašeni gotovo uvek ima dosledno silazno tonsko kretanje. U reči je najistaknutiji tonski vrhunac vokala koji sledi naglašeni slog kod 69\% primera dvosložnih i $73 \%$ primera trosložnih reči, dok se u ostalim slučajevima tonski vrhunac reči nalazi u okviru naglašenog vokala. ${ }^{7}$

Naglašeni je vokal intenzitetski dominantniji i moguće ga je opaziti kao glasnijeg kod 19\% primera dvosložnih i 38\% primera trosložnih reči, dok se prvi nenaglašeni vokal opaža kao glasniji kod 67\% dvosložnih, odnosno 38\% primera trosložnih reči. U ostalim se slučajevima naglašeni i naredni vokal opažaju kao podjadnako glasni.

3.2.2. Kada je tonsko kretanje u pitanju, rezultati našeg istraživanja uglavnom su saglasni s rezultatima do kojih je došla i Jelica Jokanović-Mihajlov. Naime, kod govornice koju uzima za predstavnicu hercegovačkog tipa ona nalazi da $\mathrm{u}$ rečima s uzlaznim akcentima naglašeni vokal ima uzlazno tonsko kretanje, između naglašenog i narednog vokala uvek je uzlazni tonski interval, a uzlaznost se nastavlja i na nenaglašenom vokalu (Jokanović-Mihajlov, 1983: 310-312), dok kod govornice iz istočne Bosne vokali pod uzlaznim akcentima imaju ravan ili ravnouzlazan ton (s malim uzlaznim intervalom), između naglašenog i narednog vokala postoji uzlazan tonski interval, a nenaglašeni vokal $\mathrm{u}$ rečima $\mathrm{s}$ dugouzlaznim

\footnotetext{
${ }^{7}$ V. primere na slikama 3 i 4.
} 
akcentom ima, uglavnom, silazno tonsko kretanje (Jokanović-Mihajlov, 1983: 315317), ove nalaze autorka potvrđuje i u kasnijim istraživanjima (Jokanović-Mihajlov, 2007: 60, 65-67). Naši se rezultati, u opštim crtama, slažu s prethodno datim opisima dugouzlaznog akcenta u realizaciji govornika iz istočnohercegovačkog dijalekta (Sredojević-Subotić, 2011b: 231), kao i s rezultatima istraživanja Ane Batas, koja nalazi da dugouzlazni akcenat u govorima hercegovačko-šumadijskog tipa ima uzlazno tonsko kretanje na naglašenom vokalu i visok naredni vokal (Batas, 2014: 283). U najvećem delu naši se rezultati slažu s opisom dugouzlaznog akcenta kod govornika iz užičkog kraja - u rečima s ovim akcentom linija f0 najčešće je blago uzlazna, a može biti i ravna, blago konkavna ili pak blago silazna, dok između naglašenog i narednog vokala postoji uzlazni interval f0 (Lončar Raičević, 2016a: 264; 2016b: 638).

Kada je intenzitet u pitanju, Jokanović-Mihajlov zapaža da je kod govornika koji pripadaju istočnohercegovačkom dijalektu inetnzitetski dominantniji naglašeni vokal (Jokanović-Mihajlov, 1983: 330; 2007: 60-65). Kod govornika iz užičkog kraja Lončar Raičević nalazi da se naglašeni i nenaglašeni vokali jasno razlikuju po intenzitetskom odnosu, ali da intenzitet ne igra sistematsku ulogu u razlikovanju akcenata (Lončar Raičević 2016a; 2016b: 638).

\subsection{NS grupa}

3.3.1. I u grupi dvosložnih i u grupi trosložnih reči na naglašenom vokalu najčešće je zabeleženo dosledno silazno tonsko kretanje. Kod $21 \%$ primera dvosložnih i $32 \%$ primera trosložnih reči na ovom je vokalu uzlazno-silazno tonsko kretanje, pri čemu je silazni deo dominantnij, a tonski vrhunac se nalazi u prvoj polovini vokala, pri samom njegovom početku. Između naglašenog i narednog vokala postoji uzlazan tonski odnos, što pokazuje odnos maksimalnih tonskih visina ovih dvaju vokala, ali i tonski interval između kraja naglašenog i početka vokala koji ga sledi. Na vokalu koji sledi naglašeni vokal u 54\% primera dvosložnih i 11\% primera trosložnih reči jeste dosledno silazno tonsko kretanje, dok je u preostalim slučajevima uzlazno-silazno tonsko kretanje, pri čemu je u $70 \%$ primera i dvosložnih i trosložnih reči dominantniji silazni deo. Tonski vrhunac reči nalazi se na drugom slogu kod $81 \%$ primera dvosložnih, odnosno kod 59\% primera trosložnih reči. Ipak, kod $29 \%$ primera trosložnih reči maksimalna f0 vokala u trećem slogu najistaknutija je u reči. ${ }^{8}$

\footnotetext{
${ }^{8} \mathrm{~V}$. primere na slikama 5 i 6.
} 
Naglašeni vokal intenzitetski je dominantniji i moguće ga je opaziti kao glasnijeg kod 33\% primera dvosložnih i 41\% primera trosložnih reči, dok se prvi nenaglašeni vokal opaža kao glasniji kod 39\% dvosložnih, odnosno 38\% primera trosložnih reči. U ostalim primerima ova dva vokala opažaju se kao podjednako glasni.

3.3.2. Kada je tonsko kretanje u pitanju, rezultati našeg istraživanja uglavnom se ne poklapaju s rezultatim istraživanja Pavla Ivića i Ilse Lehiste. Naime, vokal pod dugouzlaznim akcentom u Ivićevom je izgovoru zaista uzlazan, s vrhuncem blizu kraja. Vrhunac vokala u narednom slogu može biti viši od vrhunca naglašenog vokala ( $u$ rečima s dugim nenaglašenim vokalom) ili pak niži od njega (u rečima s kratkim nenaglašenim vokalom) (Ivić-Lehiste, 2002: 38-39). Tipične Ivićeve realizacije rečî $\mathrm{s}$ dugouzlaznim akcentom u našem se korpusu uopšte ne sreću. Kada je dvanaestoro dopunskih informatora u pitanju, kod dvoje od njih naglašeni je vokal silazan, kod šestoro je neznatno uzlazan, dok je kod četvoro izrazito uzlazan (Ivić-Lehiste, 2002: 89). Odnos tonskih vrhunaca naglašenog i narednog vokala kod devetoro je informatora uzlazan (Ivić-Lehiste, 2002: 110 112).

Pored toga, naši se rezultati ne poklapaju ni s opisom izgovora studentkinje poreklom iz Kikinde, koju Jokanović-Mihajlov uzima za tipičnu predstavnicu vojvođanskih govora, budući da u njenom govoru naglašeni vokal karakteriše uzlazno tonsko kretanje (s malim intervalom uzlaznosti), između naglašenog i narednog vokala postoji uzlazan tonski interval, dok nenaglašeni vokal ima silazno kretanje (što sa zapaža pregledom podataka datih u prilogu, iako autorka iznosi nešto drugačiji stav) (Jokanović-Mihajlov, 1983: 320-321). Rezultati istraživanja kojeg ovde predstavljamo u potpunosti se poklapaju sa svim prethodnim rezultatima ispitivanja dugouzlaznog akcenta kod govornika poreklom iz Novog Sada, vršenim na korpusima test-rečenicâ, minimalnih parova i kontinuiranog čitanog teksta (Sredojević-Subotić, 2011a: 113-116; 2011b: 232-233; Sredojević, 2015; 2017c: 63-65, 122-129). Ana Batas kod govornika vojvođanskog porekla nalazi da ton na naglašenom vokalu najpre pada, a onda se pravi tonski skok ka vokalu sledećeg sloga (Batas, 2014: 283).

Kada je intenzitet u pitanju, u Ivićevim primerima između naglašenog i narednog vokala postoji silazan intenzitetski odnos (Ivić-Lehiste, 2002: 41-45). U Ivićevoj i Lehistinoj dopunskoj grupi, razlike u intenzitetu između naglašenog i narednog vokala kod nekih su informatora bile povezane s promenama f0 karakterističnim za određene akcente, ali kod drugih takva veza nije bila uočljiva (Ivić-Lehiste, 2002: 115). Autori zaključuju da za kvalitetske distinkcije intenzitet 
uopšte nije relevantan (Ivić-Lehiste, 2002: 46). Jokanović-Mihajlov nalazi da postoji velika sličnost $\mathrm{u}$ intenzitetskom odnosu između naglašenog i narednog vokala kod govornika poreklom iz Vojvodine i kod onih iz Beograda (JokanovićMihajlov, 1983: 330; 2007: 71-96). Rezultati istraživanja kojeg ovde predstavljamo dosledno se poklapaju sa svim prethodnim rezultatima ispitivanja dugouzlaznog akcenta kod govornika poreklom iz Novog Sada (Sredojević-Subotić, 2011a: 119121; Sredojević, 2017c: 63-65, 122-129).

\subsection{Poređenje akustičkih parametara između triju grupa}

Tonsko kretanje na naglašenom vokalu - kojem odgovara uglavnom ravna linija f0 (u BG grupi), blago uzlazna (u IH grupi) ili izrazito silazna linija f0 (u NS grupi) - može biti predstavljeno rasponom f0 između početka i kraja ovog vokala. Kako vidimo iz podataka prikazanih u tebeli 2 , srednje vrednosti parametra $\mathrm{R}$ ( $\mathrm{fO}_{\mathrm{lp}}$ - $\mathrm{f0}_{1 \mathrm{k}}$ ) statistički se značajno razlikuju između BG i NS grupe, kao i između IH i NS grupe, dok razlike između BG i IH grupe nisu statistički značajne.

Uzlazan tonski odnos između naglašenog i narednog vokala opisuju vrednosti raspona f0 između tonskih vrhunaca ovih vokala, odnosno, raspona f0 između kraja naglašenog i početka narednog vokala. Kao što vidimo u tabeli 2 , srednje vrednosti parametara $\mathrm{R}\left(\mathrm{fO}_{1 \max }-\mathrm{fO}_{2 \max }\right)$ i $\mathrm{R}\left(\mathrm{fO}_{1 \mathrm{k}}-\mathrm{fO}_{2 \mathrm{p}}\right.$ ) najmanje su u BG grupi, neznatno veće u IH, a izrazito veće u NS grupi. Razlike koje postoje u srednjim vrednostima dvaju navedenih parametara statistički su značajne između BG i NS, kao i između IH i NS grupe, ali ne i između BG i IH grupe.

Srednja vrednost razlike intenziteta između naglašenog i narednog vokala (tabela 2, parametar I1 - I2) najveća je u BG, nešto manja u IH, a najmanja u NS grupi. Vrednosti posmatranog parametra statistički se značajno razlikuju između BG i NS grupe, ali ne i između IH i NS, odnosno, BG i IH grupe.

Tonski vrhunac naglašenog vokala najčešće je smešten u njegovoj prvoj polovini u BG grupi, u drugoj polovini u IH grupi, odnosno, na samom početku vokala u NS grupi. Srednje vrednosti posmatranog parametra statistički se značajno razlikuju u trima grupama međusobno (tabela 2 , parametar $\mathrm{t} 1_{\max \%}$ ).

Naglašeni vokal, u proseku, najduže trajanje ima u BG grupi, nešto kraće u IH, a najkraće u NS grupi. Ipak, između posmatranih grupa razlike u srednjem trajanju naglašenog vokala nisu statistički značajne (tabela 2, parametar t1). S druge strane, vokal koji sledi naglašeni, u proseku, najduže trajanje ima u NS grupi, zatim u BG, a najkraće u IH grupi. Srednje vrednosti parametra t2(\%t1) statistički se značajno razlikuju između BG i NS grupe, kao i između IH i NS grupe, dok razlike između BG i IH grupe nisu statistički značajne. 
Tabela 2: Parametri tona, intenziteta i trajanja u trima grupama ${ }^{9}$

\begin{tabular}{|c|c|c|c|c|c|c|c|c|}
\hline Parametar & Tip & $\mathbf{N}$ & $\overline{\mathbf{X}}$ & SD & ANOVA F & $\mathbf{p}$ & $\begin{array}{c}\text { Bonferroni } \\
\text { post hoc } \\
\text { test }\end{array}$ & $\mathbf{p}$ \\
\hline \multirow{3}{*}{$\mathbf{R}\left(\mathbf{f} \mathbf{0}_{1 \mathrm{p}}-\mathbf{f} \mathbf{0}_{1 \mathrm{k}}\right)$} & $\mathrm{BG}$ & 60 & 0 & 1,33 & \multirow{3}{*}{ 99,204 } & \multirow{3}{*}{0,000} & $\mathrm{BG}: \mathrm{IH}$ & 0,449 \\
\hline & $\mathrm{IH}$ & 74 & 0,31 & 1,12 & & & BG : NS & 0,000 \\
\hline & NS & 101 & $-2,12$ & 1,27 & & & IH : NS & 0,000 \\
\hline \multirow{3}{*}{$\begin{array}{c}\mathbf{R}\left(\mathbf{f 0}_{1 \text { max }}-\right. \\
\left.\mathbf{f 0}_{2 \text { max }}\right)\end{array}$} & $\mathrm{BG}$ & 60 & 0,58 & 1,52 & \multirow{3}{*}{16,275} & \multirow{3}{*}{0,000} & $\mathrm{BG}: \mathrm{IH}$ & 1,000 \\
\hline & $\mathrm{IH}$ & 74 & 0,79 & 1,28 & & & $\mathrm{BG}: \mathrm{NS}$ & 0,000 \\
\hline & NS & 101 & 1,83 & 1,67 & & & IH : NS & 0,000 \\
\hline \multirow{3}{*}{$R\left(\mathbf{f 0}_{1 k}-\mathbf{f 0} \mathbf{0}_{2 p}\right)$} & $\mathrm{BG}$ & 60 & 0,95 & 1,52 & \multirow{3}{*}{77,455} & \multirow{3}{*}{0,000} & $\mathrm{BG}: \mathrm{IH}$ & 1,000 \\
\hline & $\mathrm{IH}$ & 74 & 1,11 & 1,14 & & & $\mathrm{BG}: \mathrm{NS}$ & 0,000 \\
\hline & NS & 101 & 3,29 & 1,44 & & & IH : NS & 0,000 \\
\hline \multirow{3}{*}{ I1 - I2 } & $\mathrm{BG}$ & 60 & 1,53 & 3,09 & \multirow{3}{*}{5,142} & \multirow{3}{*}{$\mathbf{0 , 0 0 7}$} & BG : IH & 1,000 \\
\hline & $\mathrm{IH}$ & 74 & 1,21 & 2,47 & & & BG : NS & 0,011 \\
\hline & NS & 101 & 0,19 & 2,87 & & & IH : NS & 0,056 \\
\hline \multirow{3}{*}{$\mathbf{t} 1_{\max \%}$} & $\mathrm{BG}$ & 60 & 40,88 & 46,64 & \multirow{3}{*}{48,809} & \multirow{3}{*}{$\mathbf{0 , 0 0 0}$} & $\mathrm{BG}: \mathrm{IH}$ & $\mathbf{0 , 0 0 7}$ \\
\hline & $\mathrm{IH}$ & 74 & 60,30 & 45,09 & & & $\mathrm{BG}: \mathrm{NS}$ & 0,000 \\
\hline & NS & 101 & 6,57 & 17,48 & & & $\mathrm{IH}: \mathrm{NS}$ & 0,000 \\
\hline \multirow{3}{*}{ t1 } & BG & 60 & 146,32 & 30,16 & \multirow{3}{*}{1,969} & \multirow{3}{*}{0,142} & BG : IH & \\
\hline & $\mathrm{IH}$ & 74 & 142,39 & 34,63 & & & $\mathrm{BG}: \mathrm{NS}$ & \\
\hline & NS & 101 & 136,25 & 31,73 & & & $\mathrm{IH}: \mathrm{NS}$ & \\
\hline \multirow{3}{*}{ t2(\%t1) } & $\mathrm{BG}$ & 60 & 42,77 & 12,23 & \multirow{3}{*}{8,971} & \multirow{3}{*}{0,000} & BG : IH & 1,000 \\
\hline & $\mathrm{IH}$ & 74 & 40,92 & 16,22 & & & $\mathrm{BG}: \mathrm{NS}$ & 0,010 \\
\hline & NS & 101 & 50,05 & 15,72 & & & $\mathrm{IH}: \mathrm{NS}$ & 0,000 \\
\hline
\end{tabular}

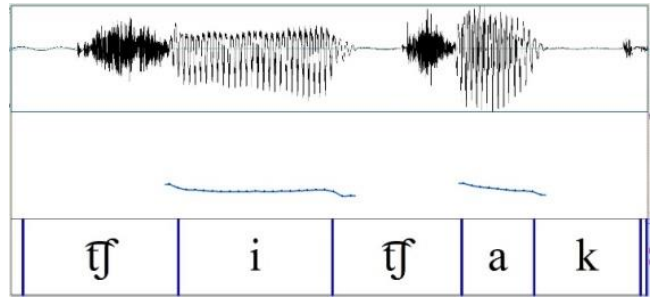

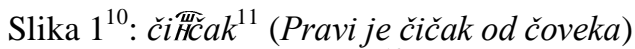
(G6) $(\mathrm{BG})^{12}$

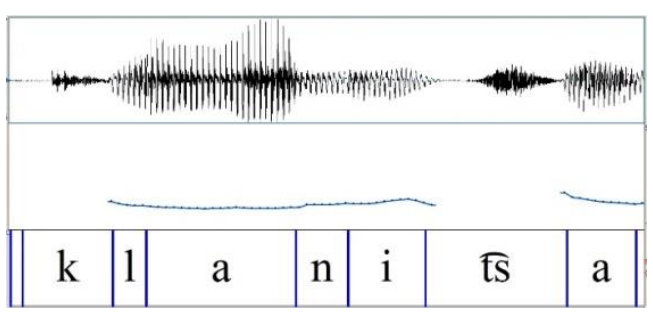

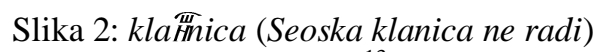
(G7) $(\mathrm{BG})^{13}$

\footnotetext{
${ }^{9} \mathrm{U}$ tabeli su za dati parametar predstavljeni podaci: broj primera $(\mathrm{N})$, srednja vrednost $(\overline{\mathrm{X}})$, standardna devijacija (SD), vrednost testa ANOVA (ANOVA F), nivo značajnosti (p). Vrednost testa koja je statistički značajna $($ za $\mathrm{p}<0,05)$ u tabeli je označena masnim fontom. ${ }^{10} \mathrm{Na}$ slikama u nastavku prikazani su oscilogram (u gornjem delu) i promene f0 (u donjem delu). Pri transkripciji primera korišćeni su simboli Međunarodnog fonetskog alfabeta (HIPA 2007).
} 


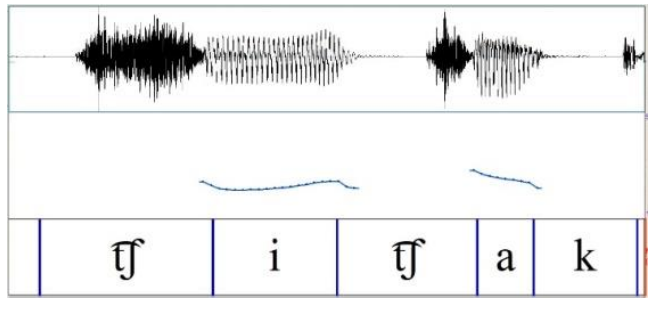

Slika 3: či i⿱⺌兀゙́ak (Pravi je čičak od čoveka) (G9) $(\mathrm{IH})^{14}$

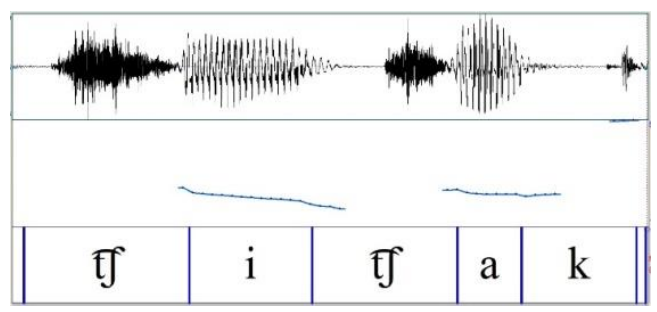

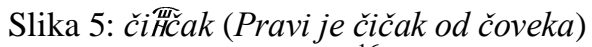
(G4) (NS) ${ }^{16}$

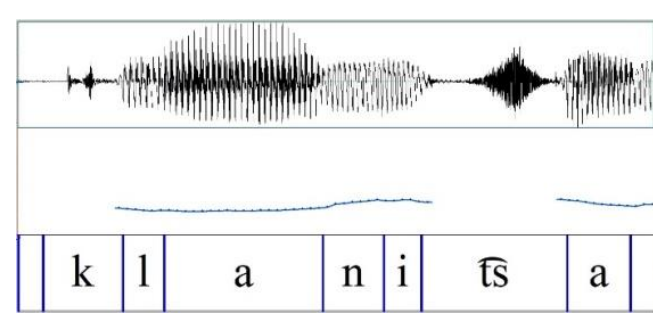

Slika 4: klaminica (Seoska klanica ne radi) (G11) (IH) $)^{15}$

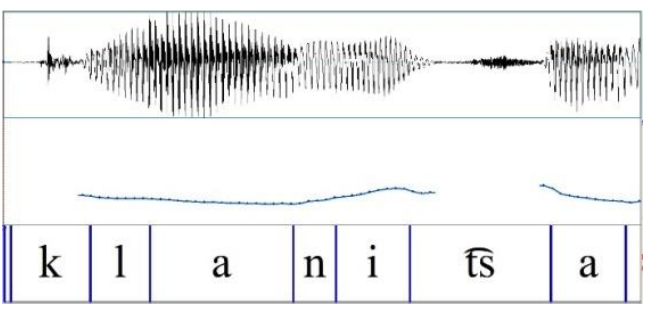

Slika 6: klaminica (Seoska klanica ne radi) (G5) (NS) ${ }^{17}$

${ }^{11}$ Kako je na spektrogramima prvi pokazatelj zvuka kod bezvučnih ploziva i afrikata u inicijalnom položaju - šum eksplozije (Bakran, 1996: 83), na slikama je mesto početka artikulacije ovih glasova označeno aproksimativno.

${ }^{12}$ [i]: $\mathrm{fO}_{\mathrm{p}}=213 \mathrm{~Hz} ; \mathrm{fO}_{\max }=213 \mathrm{~Hz} ; \mathrm{fO}_{\mathrm{k}}=206 \mathrm{~Hz} ; \mathrm{I}=70,03 \mathrm{~dB} ; \mathrm{t}=132 \mathrm{~ms}$. [a]: $\mathrm{fO}_{\mathrm{p}}=234 \mathrm{~Hz} ; \mathrm{fO}_{\max }=234 \mathrm{~Hz} ; \mathrm{fO}_{\mathrm{k}}=202 \mathrm{~Hz} ; \mathrm{I}=72,82 \mathrm{~dB} ; \mathrm{t}=61 \mathrm{~ms}$.

${ }^{13}$ [a]: $\mathrm{fO}_{\mathrm{p}}=187 \mathrm{~Hz} ; \mathrm{fO}_{\max }=187 \mathrm{~Hz} ; \mathrm{fO}_{\mathrm{k}}=184 \mathrm{~Hz} ; \mathrm{I}=72,58 \mathrm{~dB} ; \mathrm{t}=144 \mathrm{~ms}$. [i]: $\mathrm{fO}_{\mathrm{p}}=198 \mathrm{~Hz} ; \mathrm{fO}_{\max }=214 \mathrm{~Hz} ; \mathrm{fO}_{\mathrm{k}}=201 \mathrm{~Hz} ; \mathrm{I}=66,37 \mathrm{~dB} ; \mathrm{t}=74 \mathrm{~ms}$. [a]: $\mathrm{fO}_{\mathrm{p}}=222 \mathrm{~Hz} ; \mathrm{fO}_{\max }=222 \mathrm{~Hz} ; \mathrm{fO}_{\mathrm{k}}=197 \mathrm{~Hz} ; \mathrm{I}=69,3 \mathrm{~dB} ; \mathrm{t}=66 \mathrm{~ms}$. ${ }^{14}$ [i]: $\mathrm{fO}_{\mathrm{p}}=217 \mathrm{~Hz} ; \mathrm{fO}_{\max }=241 \mathrm{~Hz} ; \mathrm{fO}_{\mathrm{k}}=241 \mathrm{~Hz} ; \mathrm{I}=75,09 \mathrm{~dB} ; \mathrm{t}=118 \mathrm{~ms}$. [a]: $\mathrm{fO}_{\mathrm{p}}=268 \mathrm{~Hz} ; \mathrm{fO}_{\max }=268 \mathrm{~Hz} ; \mathrm{fO}_{\mathrm{k}}=236 \mathrm{~Hz} ; \mathrm{I}=75,93 \mathrm{~dB} ; \mathrm{t}=51 \mathrm{~ms}$. ${ }^{15}$ [a]: $\mathrm{fO}_{\mathrm{p}}=191 \mathrm{~Hz} ; \mathrm{fO}_{\max }=200 \mathrm{~Hz} ; \mathrm{fO}_{\mathrm{k}}=200 \mathrm{~Hz} ; \mathrm{I}=79,41 \mathrm{~dB} ; \mathrm{t}=142 \mathrm{~ms}$. [i]: $\mathrm{fO}_{\mathrm{p}}=231 \mathrm{~Hz} ; \mathrm{fO}_{\max }=231 \mathrm{~Hz} ; \mathrm{fO}_{\mathrm{k}}=224 \mathrm{~Hz} ; \mathrm{I}=77,22 \mathrm{~dB} ; \mathrm{t}=34 \mathrm{~ms}$. [a]: $\mathrm{fO}_{\mathrm{p}}=228 \mathrm{~Hz} ; \mathrm{fO}_{\max }=228 \mathrm{~Hz} ; \mathrm{fO}_{\mathrm{k}}=208 \mathrm{~Hz} ; \mathrm{I}=78,62 \mathrm{~dB} ; \mathrm{t}=56 \mathrm{~ms}$. ${ }^{16}[\mathrm{i}]: \mathrm{fO}_{\mathrm{p}}=227 \mathrm{~Hz} ; \mathrm{fO}_{\max }=227 \mathrm{~Hz} ; \mathrm{fO}_{\mathrm{k}}=183 \mathrm{~Hz} ; \mathrm{I}=71,13 \mathrm{~dB} ; \mathrm{t}=96 \mathrm{~ms}$. [a]: $\mathrm{fO}_{\mathrm{p}}=233 \mathrm{~Hz} ; \mathrm{fO}_{\max }=233 \mathrm{~Hz} ; \mathrm{fO}_{\mathrm{k}}=220 \mathrm{~Hz} ; \mathrm{I}=74,46 \mathrm{~dB} ; \mathrm{t}=48 \mathrm{~ms}$. ${ }^{17}$ [a]: $\mathrm{fO}_{\mathrm{p}}=198 \mathrm{~Hz} ; \mathrm{fO}_{\max }=198 \mathrm{~Hz} ; \mathrm{fO}_{\mathrm{k}}=179 \mathrm{~Hz} ; \mathrm{I}=78,65 \mathrm{~dB} ; \mathrm{t}=126 \mathrm{~ms}$. [i]: $\mathrm{fO}_{\mathrm{p}}=204 \mathrm{~Hz} ; \mathrm{fO}_{\max }=237 \mathrm{~Hz} ; \mathrm{fO}_{\mathrm{k}}=234 \mathrm{~Hz} ; \mathrm{I}=75,92 \mathrm{~dB} ; \mathrm{t}=63 \mathrm{~ms}$. [a]: $\mathrm{fO}_{\mathrm{p}}=236 \mathrm{~Hz} ; \mathrm{fO}_{\max }=236 \mathrm{~Hz} ; \mathrm{fO}_{\mathrm{k}}=189 \mathrm{~Hz} ; \mathrm{I}=76,21 \mathrm{~dB} ; \mathrm{t}=63 \mathrm{~ms}$. 


\section{ZAKLJUČAK}

Naše je istraživanje pokazalo da se u primerima govornica poreklom iz Novog Sada, Beograda i s područja istočnohercegovačkog dijalekta čiji smo govor ispitivali javljaju dva tipa fonetskih realizacija dugouzlaznog akcenta. Iako su primeri obaju tipova zabeleženi u svim ispitivanim grupama, za svaku od grupa karakterističan je samo jedan tip realizacije ovog akcenta.

Kada je u pitanju tonsko kretanje na naglašenom vokalu i tonski i intenzitetski odnosi između naglašenog i narednog vokala između primera govornica poreklom iz Beograda i onih s područja istočnohercegovačkog dijalekta nema statistički značajnih razlika. Drugim rečima, dugouzlazni se akcenat u BG i IH grupi realizuje na istovetan način. Ove realizacije karakteriše ravna ili blago uzlazna linija f0 na naglašenom vokalu i manji uzlazni tonski interval između kraja tog i početka narednog vokala. Pojedine razlike koje postoje u parametrima tona i intenziteta između ovih dveju grupa malog su obima, nisu statistički značajne i nalaze se ispod praga percepcije (Rietveld-Gussenhoven, 1985: 304; Nootebom, 1997: 645).

S druge strane, po karakteristikama tonskog kretanja, realizacije dugouzlaznog akcenta u NS grupi statistički se značajno razlikuju od onih u BG i IH grupi. Tipično za realizaciju ovog akcenta kod govornica poreklom iz Novog Sada jeste silazna linija fo na naglašenom vokalu i veliki uzlazni interval između naglašenog i narednog vokala. Razlike u parametrima tona koje postoje između NS i BG, odnosno, NS i IH grupe mogu biti opažene u komunikaciji.

I intenzitetski odnosi između naglašenog i narednog vokala veoma su slični u BG i IH grupi, a drugačiji u NS grupi. Ipak, kada je u pitanju parametar intenziteta statistički značajne razlike postoje samo između NS i BG grupe.

Trajanje naglašenog vokala približno je jednako $u$ realizacijama dugouzlaznog akcenta tipičnim za NS, BG i IH grupu i između grupa po ovom parametru nema statistički značajnih razlika.

Kada su u pitanju ostali posmatrani parametri koji se tiču položaja tonskog vrhunca i trajanja prvog nenaglašenog vokala, između posmatranih grupa postoje izvesne razlike, koje mogu doprineti oblikovanju fonetskih realizacija dugouzlaznog akcenta tipičnih za ispitivane govore. I pored toga, ovi parametri nisu fonološki relevantni za uspostavljanje kvalitetskih distinkcija među akcentima (Sredojević, 2017c: 221, 223).

Uzimajući u obzir broj, poreklo i starosnu dob odabranih govornica, možemo reći da su u ovom radu predstavljeni preliminarni rezultati opisa posmatranih prozodijskih pojava u navedenim govorima. Metodologiju primenjenu u ovom radu i u sličnim radovima (Sredojević, 2017a; 2017b) treba koristiti i u narednim 
istraživanjima navedenih, ali i drugih štokavskih govora, kako bi postojeći fonološki opisi srpskog jezika bili upotpunjeni relevantnim podacima koji se međusobno mogu porediti.

Dejan Sredojević

ON DIFFERENT REALIZATIONS OF LONG RISING ACCENT IN SERBIAN

\section{Summary}

A number of studies in the past sixty years dealt with the description of the acoustic characteristics of New Stokavian accents in the dialects of the Serbian language. However, due to the different criteria applied in their research methodologies, it is often difficult to state whether the acoustic parameters studied are significantly different in different dialects. Since there is no general consensus among researchers about the typical realization of the long rising accent, we undertook to investigate this accent type in the present study. The study analyses the typical realizations of long rising accent in 12 female speakers from Belgrade, Novi Sad and different parts of the Eastern Herzegovinian dialect (BG, NS and EH groups respectively). The study included 235 examples of 14 disyllabic and 7 trisyllabic words containing long rising accent. The acoustic parameters related to pitch, intensity and duration were statistically analyzed. The data were compared to those found in earlier studies of these dialects. Our results point to two different phonetic realizations of the long rising accent in the speech of our subjects. In terms of pitch and intensity, the BG and $\mathrm{EH}$ groups exhibit no statistically different measures, while the NS group is different from both BG and EH group. Duration features do not differ statistically across the groups.

Key words: Long rising accent, fundamental frequency, intensity, duration, Belgrade speech, Novi Sad speech, Eastern Herzegovinian dialect.

\section{LITERATURA}

Baken, R. J.-Orlikoff, R. F. (2000). Clinical Measurement of Speech and Voice $\left(^{\text {nd }}\right.$ Edition). San Diego: Singular Thomson Learning.

Bakran, J. (1996). Zvučna slika hrvatskoga govora. Zagreb: Ibis grafika.

Batas, A. (2014). Fonetska i akcenatska promenljivost reči u kontinualnom govoru. Beograd: Filološki fakultet, 2014. [doktorska disertacija] (štampano ćirilicom)

Boersma, P.-Weenink, D. (2011). Praat: doing phonetics by computer (Version 5.2.28) [Computer program]. Retrieved 28 June 2017 from http://www.praat.org.

Everest, F. A. $\left(2001^{4}\right)$. Master Handbook of Acoustics. New York: McGraw-Hill. 
HIPA (2007). Handbook of the International Phonetic Association: A Guide to the Use of the International Phonetic Alphabet. International Phonetic Association (ed.). Cambridge University Press.

Ivić, P.-Lehiste, I. (1996). Prozodija reči i rečenice u srpskohrvatskom jeziku. Sremski Karlovci - Novi Sad: Izdavačka knjižarnica Zorana Stojanovića, 1996. (štampano ćirilicom)

Ivić, P.-Lehiste, I. (2002). O srpskohrvatskim akcentima. Sremski Karlovci - Novi Sad: Izdavačka knjižarnica Zorana Stojanovića. (štampano ćirilicom)

Jokanović-Mihajlov, J. (1983). Priroda uzlaznih akcenata u progresivnijim štokavskim govorima. Srpski dijalektološki zbornik, XXIX, 295-338. (štampano ćirilicom)

Jokanović-Mihajlov, J. (2007). Akcenat $i$ intonacija govora na radiju $i$ televiziji. Beograd: Društvo za srpski jezik i književnost Srbije. (štampano ćirilicom)

Lončar Raičević, A. (2016a). Prozodija reči u govoru užičkog kraja. Banja Luka: Filološki fakultet. [doktorska disertacija] (štampano ćirilicom)

Lončar Raičević, A. (2016b). Prilog proučavanju prirode akcenata u srpskom jeziku. Srpski jezik, XXI, 627-639. (štampano ćirilicom)

Lončar Raičević, A.-Sudimac, N. (2017). Akustički opis naglaska u govorima prizrensko-južnomoravskog dijalekta. Zbornik Matice srpske za filologiju $i$ lingvistiku, LX/2, 209-225. (štampano ćirilicom)

Lončar Raičević, A.-Sudimac, N. (2018). Akustički opis naglaska u govorima timočko-lužničkog dijalekta. Philologia Mediana, X/10, 423-439. (štampano ćirilicom)

Masing, L. (1876). Die Hauptformen des serbisch-chorwatischen Accents: nebst einleitenden Bemerkungen zur Accentlehre insbesondere des Griechischen und des Sanskrit: Inauguraldissertation, zur Erlangung des philosophischen Doktorgrades verfasst und der hohen philosophischen Facultät an der Universität zu Leipzig eingereicht von Leonhard Masing. Mémoires de l'Académie Impériale des Sciences de St.-Pétersbourg. Ser. 7 ; T. 23, $\mathrm{N}^{\circ}$ 5, 1876. [doktorska disertacija].

Nootebom, S. (1997). The Prosody of Speech: Melody and Rhythm. In: Hardcastle, W. J.- Laver, J. (Eds.). The Handbook of Phonetic Sciences. Oxford: Basil Blackwell Limited. 640-673.

Petrović, D.-Gudurić, S. (2010). Fonologija srpkoga jezika, Beograd - Novi Sad: SANU. Institut za srpski jezik - Beogradska knjiga - Matica srpska. (štampano ćirilicom) 
Rietveld, A.C.M.-Gussenhoven, C. (1985). On the Relation Between Pitch Excursion Size and Pitch Prominence. Journal of Phonetics, 13, 299-308.

Sredojević, D. (2011). Eksperimentalno-fonetsko ispitivanje prozodijskih karakteristika novosadskog govora. Novi Sad: Filozofski fakultet. [doktorska disertacija] (štampano ćirilicom)

Sredojević, D. (2015). Eksperimentalno-fonetsko ispitivanje distinkcija između dugosilaznog i dugouzlaznog akcenta u novosadskom govoru. U: Gudurić, S.-Stefanović, M. (ured.) (2015). Jezici i kulture u vremenu i prostoru IV/2. Novi Sad: Filozofski fakultet. 335-342.

Sredojević, D. (2016a). Kratkouzlazni akcenat u govoru studenata žurnalistike poreklom iz nečetvoroakcenatskih oblasti. U: Pralica, D.-Šinković, N. (ured.) (2016). Digitalne medijske tehnologije $i$ društveno-obrazovne promene 5. Novi Sad: Filozofski fakultet. 235-246.

Sredojević, D. (2016b). Fonološki značaj različitih fonetskih karakteristika pri uspostavljanju distinkcije kvaliteta između kratkih akcenata u pojedinim govorima Srema, Banata i Bačke. U: Dražić, J.-Bjelaković, I. \& Sredojević, D. (ured.) (2016). Teme jezikoslovne u srbistici kroz dijahroniju i sinhroniju. Zbornik u čast Ljiljani Subotić. Novi Sad: Filozofski fakultet. 279-292.

Sredojević, D. (2017a). How Much Do Phonetic Realisations of Serbian Accents Actually Differ from Each Other in Various Dialects? Godišnjak Filozofskog fakulteta u Novom Sadu, 42/1, 323-337.

Sredojević, D. (2017b). Fonetske razlike između fonološki istih akcenata u različitim vojvođanskim govorima. U: Gudurić, S.-Radić-Bojanić, B. (ured.) (2017). Jezici i kulture u vremenu i prostoru VI. Novi Sad: Filozofski fakultet. 341350.

Sredojević, D. (2017c). Fonetsko-fonološki opis akcenata u standardnom srpskom jeziku - od specifičnog ka opštem. Novi Sad: Filozofski fakultet.

Sredojević, D.-Subotić, Lj. (2011a). Dugouzlazni akcenat u novosadskom govoru: fonetske karakteristike i fonološka interpretacija. Zbornik Matice srpske za filologiju i lingvistiku, LIV/2, 108-133. (štampano ćirilicom)

Sredojević, D.-Subotić, Lj. (2011b). The Neo-Štokavian Accent Shift and the Phonological Significance of Suprasegmental Features in Different Štokavian Dialects. Acoustic and Phonetic Analysis. Baltistica, Priedas VII, 227-242.

't Hart, J.-Collier, R. \& Cohen, A. (2006). A Perceptual Study of Intonation: An Experimental-Phonetic Approach to Speech Melody. Cambridge University Press. 